\title{
The pharmacology of Equisetum arvense- A review
}

\author{
Prof Dr Ali Esmail Al-Snafi \\ Department of Pharmacology, College of Medicine, Thi qar University, Iraq.
}

\begin{abstract}
The previous studies revealed that Equisetum arvense contained alkaloids, carbohydrate, proteins and amino acids, phytosterols, saponins, sterols, ascorbic acid, silicic acid, phenol , tannin, flavonoids, triterpenoids, volatile oils and many other biological active constituents. The pharmacological studies showed that it possessed antioxidant, anticancer, antimicrobial, smooth muscle relaxant effects of the vessels and ileum, anticonvulsant, sedative, anti-anxiety, dermatological immunological, antinociceptive, anti-inflammatory, antidiabetic, diuretic, inhibition of platelet aggregation, promotion of osteoblastic response, anti-leishmanial, and many other effects. The current review highlights the chemical constituents and pharmacological effects of Equisetum arvense.
\end{abstract}

Keywords: constituents, chemical, pharmacology, Equisetum arvense

Plant profile:

\section{INTRODUCTION:}

Plants are a valuable source of a wide range of secondary metabolites, which are used as pharmaceuticals, agrochemicals, flavours, fragrances, colours, biopesticides and food additives [1-50]. Equisetum arvense belong to Equisetaceae family contained alkaloids, carbohydrate, proteins and amino acids, phytosterols, saponins, sterols, ascorbic acid, silicic acid, phenol, tannin, flavonoids, triterpenoids, volatile oils and many other biological active constituents. The pharmacological studies showed that it possessed antioxidant, anticancer, antimicrobial, smooth muscle relaxant effects of the vessels and ileum, anticonvulsant, sedative, anti-anxiety, dermatological immunological, antinociceptive, anti-inflammatory, antidiabetic, diuretic, inhibition of platelet aggregation, promotion of osteoblastic response, anti-leishmanial, and many other effects. This review will highlight the chemical constituents and pharmacological effects of Equisetum arvense.

Synonyms: Equisetum arvense var. alpestre, Equisetum arvense var. boreale, Equisetum arvense var. campestre, Equisetum arvense var. riparium and Equisetum caldera B. Boivin [51-52].

\section{COMMON NAMES:}

Arabic: kinbat, kinbat el-hokol, thail el-faras, thanb el-faras; English: common horsetail, field horsetail; French: prêle des champs; German: Akerschachtelhalm; Japanese: sugi-na, tsukushi; Spanish: cola de caballo; Swedish: åkerfräken[53].

\section{TAXONOMIC CLASSIFICATION:}

Kingdom: Plantae, Subkingdom: Tracheobionta Division: Equisetophyta, Class: Equisetopsida, Order: Equisetales, Family: Equisetaceae, Genus: Equisetum, Species: Equisetum arvense [54].

\section{DISTRIBUTION:}

The plant was distributed in Asia (Armenia, Azerbaijan, Georgia, Russian Federation, China, Japan, Korea, azakhstan, Kyrgyzstan, Tajikistan, Turkmenistan, Uzbekistan, Mongolia, Iran, Iraq, Lebanon, Turkey, Bhutan, India and Nepal); Europe: (Belarus, Estonia, Latvia, Lithuania, Moldova, Russian Federation -European part, Ukraine, Austria, Belgium, Czech Republic, Germany, Hungary, Netherlands, Poland, Slovakia, Switzerland, Denmark, Finland, Iceland, Ireland, Norway, Svalbard, Sweden, United Kingdom, Albania, Bosnia, Herzegovina, Bulgaria, Croatia, Greece, Italy, Montenegro, Romania, Serbia, Slovenia, France, Portugal and Spain); Northern America: (Canada and United States)[53].

\section{DESCRIPTION:}

Aerial stems dimorphic; vegetative stems green, branched, 2-60(-100) cm; hollow center 1/3-2/3 stem diameter. Sheaths squarish in face view, 2-5(-10) $\times 2-5(-9) \mathrm{mm}$; teeth dark, 4-14, narrow, 1-3.5 mm, often cohering in pairs. Branches in regular whorls, ascending, solid; ridges 3-4; valleys channeled; 1st internode of each branch longer than subtending stem sheath; sheath teeth attenuate. Fertile stems brown, lacking stomates, unbranched, shorter than vegetative stems, with larger sheaths, fleshy, ephemeral[54]. 


\section{TRADITIONAL USES:}

Equisetum arvense was used traditionally for tuberculosis, as a catarrh in the kidney and bladder regions, as a hematostatic for profuse menstruation, nasal, pulmonary and gastric hemorrhages, for brittle fingernails and loss of hair, for rheumatic diseases, gout, poorly healing wounds and ulcers, swelling and fractures and for frostbite [55].

\section{PHYSICOCHEMICAL CHARACTERISTICS AND CHEMICAL CONSTITUENTS:}

\section{Physicochemical characteristics:}

The physicochemical characteristics of stems of Equisetum arvense \% w/w (dried plant) were: ethanol soluble extractive: 4.32 , water soluble extractive: 15.45 , ether soluble extractive: $3.52 \%$, total ash: 22 , acid insoluble ash: 11 , water soluble ash: 8 , loss on drying: 12.5 , moisture content: 15 , volatile oil: 1.5 , foaming index 100 ( height of foam in every tube is less than $1 \mathrm{~cm}$ ) [56].

\section{CHEMICAL CONSTITUENTS:}

The preliminary phytochemical analysis showed that the plant contained alkaloids, carbohydrate, proteins and amino acids, phytosterols, saponins, sterols, ascorbic acid, silicic acid, phenol, tannin flavonoids and triterpenoids [56-59].The plant contained silicic acid, tartaric acid, methyl esters of protocatechuic, caffeic acids isoquercitrin, apigenin and kaempferol as phenolic compounds [58, 60-62].Stem contained silicic acid and silicates (5-8\%), calcium (1.3\%), potassium (1.8\%) and other minerals such as aluminium, sulphur, phosphorus, sodium, zinc, magnesium and manganese [63-66]. Alkaloids such as nicotine, palustrine and palustrinine were isolated from the plant [67]. The total phenolic content of $n$-butanol, ethyl acetate and water extracts were 96.4, 26.4 and $15.4 \mathrm{mg} / \mathrm{g}$ of dry extracts, respectively [68]. The plant contained 0.6 to $0.9 \%$ flavonoids including apigenin-5-0-glucoside, genkwanin-5-O-glucoside, kaempferol-3,7-di-0-glucoside, kaempferol- 3-0-(6'-0-malonylglucoside)-7-0-glucoside, kaempferol-3-O-sophoroside, luteolin-5-O-glucoside, quercetin-3-O-glucoside. It was also contained caffeic acid ester (up to $1 \%$ including chlorogenic acid, dicoffeoyl-meso-tartaric acid), $5-7.7 \%$ silicic acid and pyridine alkaloids, and styrolpyrone glucosides [56, 60, 63,69-73]. Equisetumoside A (3methoxy-11,12-dihydroxy-phenylhexane-9-one-4-O- $\beta$-D-glucopyranoside), equisetumoside B (3-methoxy-4,11dihydroxy-phenylhexane-9-one-12-O- $\beta$-D-glucopyranoside), equisetumoside $\mathrm{C}$ ( cis -ferulic acid potassium salt 4O- $\beta$-D-glucopyranoside), uridine, inosine, $2^{\prime}$-deoxyinosine, $2^{\prime}$-deoxycytidine, tryptophan, thymidine, 5-carboxy-2'deoxyuridine, coniferin, and kaempferol 3-O- $\beta$-D-sophoroside-7-O- $\beta$-D-glucopyranoside were isolated from the water-soluble extract of fertile sprouts of Equisetum arvense[74].The volatile constituents of the sterile stems of Equisetum arvense were investigated using GC, GC/MS and 13C-NMR. Twenty-five compounds were identified. Hexahydrofarnesyl acetone (18.34\%), cis-geranyl acetone (13.74\%), thymol (12.09\%) and trans-phytol (10.06\%) were the major constituents [75].

\section{PHARMACOLOGICAL EFFECTS:}

Antioxidant effect:

The plant contained high amount of polyphenols. Antioxidant activity (ABTS assay) was estimated to be $98.13 \pm 3.84$ ( $\mu \mathrm{M}$ Trolox equivalents/g dry weight) [76]. The total phenol content, total antioxidant capacity and silicic acid amount were found to be $18.67 \%, 123 \mathrm{mg}$ gallic acid/g dry weight extract, $1608 \mu \mathrm{M} \mathrm{TEAC} / \mathrm{mg}$ dry weight extract and $0.0049 \mathrm{mg}$ silicic acid/mg dry weight extract, respectively [77].Aqueous and ethanol extract from top and body portions of field horsetail were tested for antioxidative activity using four different methods. The ethanol extract fractions of each portion were richer in total phenolic components than water extracts. These fractions had remarkable antioxidative activities, similar to that of $5 \mathrm{mM}$ ascorbic acid. Water extracts of both portions showed high superoxide anion radical-scavenging activities. Hydroxyl radicals were effectively scavenged by ethanol extracts. Field horsetail was rich in vitamins C and E. and contained high levels of copper and zinc. These were essential elements, for superoxide dismutase to act against active oxygen species [78].

The antioxidative activity of different horsetail (Equisetum arvense) extracts was studied by the electron spin resonance spectroscopy-spin trapping method. The influence of different horsetail extracts during lipid peroxidation of sunflower oil induced by the lipophilic azo-initiator 4,4'-azobis(4-cyanovaleric acid) and soybean phosphatidylcholine liposomes induced by the hydrophilic azo-initiator 2,2'-azobis(2-amidinopropane) dihydrochloride was investigated. The results of electron spin resonance analysis confirmed that the extracts suppressed the formation of lipid peroxyl radicals in both systems investigated, in a dose-dependent manner. The results indicate that n-butanol, methanol, ethyl acetate, and water extracts had significant peroxyl radical scavenging activity [67].The antioxidant activity and phenolic composition of three different extracts (ethanol, nbutanol and water) of field horsetail (Equisetum arvense) were investigated by measuring the total reducing power (expressed by ascorbate equivalent antioxidant capacity-AEAC), inhibition of lipid peroxidation, and free radical scavenging capacity (RSC) towards 2,2-diphenyl-1- picrylhydrazyl (DPPH radical) and nitric oxide (NO). The results showed that the highest radical scavenging capacity regarding both DPPH and NO radicals was expressed 
by ethanol extract $\left(\mathrm{EC}_{50}=2.37 \mu \mathrm{g} / \mathrm{ml}\right.$ and $\mathrm{EC}_{50}=90.07 \mu \mathrm{g} / \mathrm{ml}$, respectively), and the lowest by water extract $\left(\mathrm{EC}_{50}=37.2 \mu \mathrm{g} / \mathrm{ml}\right.$ and $\mathrm{EC}_{50}>333.33 \mu \mathrm{g} / \mathrm{ml}$, respectively), while, n-butanol extract showed the highest total reducing power $(\mathrm{AEAC}=13.40 \mu \mathrm{g} / \mathrm{ml}$ ) [58]. DPPH scavenging activity of Equisetum arvense was $96.2 \%$ at 4.0 $\mathrm{mg} / \mathrm{ml}$ foliage and central stalk, while, DPPH scavenging activity for rhizomatous stem and root was $94.7 \%$ at same concentration [79]. The antioxidative activity of horsetail extracts was tested by measuring their ability to scavenge stable 2,2-diphenyl-1-picrylhydrazyl (DPPH) and reactive hydroxyl radicals by electron spin resonance spectroscopy. The results demonstrated that the free radical scavenging activity (versus both DPPH and hydroxyl radicals) depended on the type and concentration of applied extracts; the highest $\mathrm{DPPH}\left(\mathrm{EC}_{50}=0.65 \mathrm{mg} / \mathrm{ml}\right) \mathrm{and}$ hydroxyl radical scavenging activities $\left(\mathrm{EC}_{50}=0.74 \mathrm{mg} / \mathrm{ml}\right)$ were obtained in the case of $n$-butanol extract. The radical scavenging activity of extracts significantly correlated with total phenolic content [68]. Onitin and luteolin isolated from the methanolic extract of Equisetum arvense showed superoxide scavenging effects $\left(\mathrm{IC}_{50}=35.3 \pm 0.2\right.$ microM and $5.9 \pm 0.3$ microM, respectively) and $\mathrm{DPPH}$ free radical scavenging effect was ( $\mathrm{IC}_{50}$ of $35.8 \pm 0.4$ microM and $22.7 \pm 2.8$ microM, respectively) [69].

\section{Anticancer effect:}

The antiproliferative activity of different horsetail (Equisetum arvense) extracts was studied using the sulforhodamine B colorimetric assay on the human cancer cell lines HeLa, HT-29, and MCF7. The antiproliferative of the extracts was depended on cell line, type of extract, and extract concentration. Ethyl acetate extract exhibited the most prominent antiproliferative effect, without inducing any cell growth stimulation on human tumor cell lines [67]. Mouse fibroblasts cell culture (NCTC cell line clone L929) was used to study the effect of polyherbal extract (70\% ethanolic extract: $4 \mathrm{~g}$ Equisetum arvense, $3 \mathrm{~g}$ Achillea millefolium, $2.5 \mathrm{~g}$ Echinacea purpurea and $0.5 \mathrm{~g}$ Hyssopus officinalis. ) on collagen secretion. Cells were supplemented with $5 \%$ FCS, containing different concentrations of polyherbal extract $(35-140 \mu \mathrm{g} / \mathrm{ml})$. The results showed a significantly $(\mathrm{P}<0.05)$ increase of collagen synthesis in the culture medium of fibroblasts treated with 70 and $140 \mu \mathrm{g} / \mathrm{ml}$ polyherbal extract, after $48 \mathrm{~h}$ and $72 \mathrm{~h}$ of cultivation. It was observed that the collagen synthesis was almost 2 times higher in cultures treated with $140 \mu \mathrm{g} / \mathrm{ml}$ polyherbal extract, for $72 \mathrm{~h}$, compared to the value obtained in the control group [76].The water extract from sterile stems of Equisetum arvense exerted dose dependent cytotoxic effects on human leukemic U 937 cells. DNA fragmentation, externalisation of phosphatidilserine, the colapse of mithocondrial transmemhrane potential, were all observed in cells cultured for $48 \mathrm{~h}$ with the herb extract. The authors concluded that the cytotoxicity of Equisetum arvense water extract against U 937 cells was due to apoptosis [80]. The antiproliferative effect of Equisetum arvense extract was tested on melanoma B16 cells. At a concentration of $>0.5 \mathrm{mg} / \mathrm{ml}$, it showed significant antiproliferative effect [81]. The cytotoxicity of the methanolic extract of the dried aerial part of Equisetum arvense was tested against various cancer cell lines including cervical adenocarcinoma, lung fibroblast, breast adenocarcinoma, and human embryonic kidney cells. After 72 hours treatment, the cells were assayed to determine the relative percentages of dead and live cells. The extract induced death on the four tested cell lines with the greatest effect on human embryonic kidney cells followed by breast adenocarcinoma. However, the extent of toxicity varied depending on the cell type and the concentration of the used extract. Compared to untreated cells, the plant extract had a profound cytotoxic effect on the breast cancer cell line. This effect was concentration-dependent, where $50 \mu \mathrm{g} / \mathrm{ml}$ had a larger effect than 20 $\mu \mathrm{g} / \mathrm{ml}$. A cytotoxic effect was also observed on the embryonic kidney cell line, $50 \mu \mathrm{g} / \mathrm{ml}$ showed more activity than $20 \mu \mathrm{g} / \mathrm{m}$, On HeLa cells, only a very slight difference was observed when extract-treated cells were compared to untreated cells [82]. The crude Equisetum arvense protein extract inhibited cancer cell proliferation in cell culture of L-1210 ( mouse derived leukemia cells), 3T3 (mouse derived SV-transformed fibroblasts) and HMV-1 ( human derived melanin producing melanoma cells). It also caused life prolongation in mice in an in vivo study using L-1210 and B16F1 (mouse melanoma cells) [83-84].Concentrations range between 100-3000 $\mu \mathrm{g} / \mathrm{ml}$ were tested for the first trial to determine $\mathrm{IC}_{50}$ value, which was appeared as $500 \mu \mathrm{g} / \mathrm{ml}$ in 48 hour. For this concentration, viability was determined as $49.61 \%$. Cytotoxic evaluation of $\mathrm{IC}_{50}$ for 24,48 and 72 hour was compared with total phenol content and antioxidant activity of the extracts. Strong correlation was recorded between cytotoxic activity and antioxidant activity and total phenol content. A significantly higher cytotoxic activity was processed with extraction medium containing $90 \%$ ethanol for 12 hour, while extracts obtained with $10 \%$ ethanol for 2 hour did not decrease the viability upon exposure to fibroblast cells [77].

\section{Antimicrobial effect:}

The methanolic extract of the aerial parts of Equisetum arvense displayed antibacterial activity against Escherichia coli at high concentration $(1 \mathrm{~g} / \mathrm{ml})$ [82]. Equisetum arvense extracts showed antimicrobial activity against Staphylococcus epidermidis and Escherichia coli, but it possessed no effect against Candida albicans. A disk diffusion method was used for the evaluation of the antimicrobial activity of volatile constituents of Equisetum arvense against Staphylococcus aureus, Escherichia coli, Klebsiella pneumoniae, Pseudomonas aeruginosa and Salmonella enteritidis. The antifungal activity of the oil was studied against Aspergillus niger 
and Candida albicans. The 1:10 dilution of the essential oil of Equisetum arvense possessed a broad spectrum and very strong antimicrobial activity against all the tested bacteria and fungi [77].The antibacterial activity of ethanolic and aqueous extract of Equisetum arvense was screened against selected urinary tract pathogens (E.coli, Klebsiella pneumonia, Proteus mirabilis, Pseudomonas aeruginosa, Staphylococcus aureus, Staphylococcus saprophyticus and Enterococcus faecalis) using disc diffusion technique. Both the extracts at different concentration exhibited antibacterial activity against all the tested bacterial strains. Ethanolic extract exhibited comparably a high degree of activity than the aqueous extract. The ethanolic extract was more effective against E.coli, Proteus mirabilis and Staphylococcus saprophyticus with a zone of inhibition of $24 \mathrm{~mm}, 23 \mathrm{~mm}$ and $24 \mathrm{~mm}$ diameter (at concentration of $1000 \mu \mathrm{g}$ ) respectively and was least effective against Pseudomonas aeruginosa with zone of inhibition of $11 \mathrm{~mm}$ (at concentration of $1000 \mu \mathrm{g}$ ). Among the other studied bacterial species, Klebsiella pneumoniae and Enterococcus faecalis showed a zone of inhibition of $18 \mathrm{~mm}$ diameter (at concentration of $1000 \mu \mathrm{g}$ ) and Staphylococcus aureus showed inhibition zone of $14 \mathrm{~mm}$ diameter (at concentration of $1000 \mu \mathrm{g}$ ) [85].The in vitro antibacterial activity of ethanol stem extract $(50-400 \mu \mathrm{g} / \mathrm{ml})$ of Equisetum arvense was studied against two Gram positive (Bacillus subtilis and Micrococcus luteus) and four Gram negative (Vibrio cholerae, Escherichia coli, Shigella flexneri and Shigella dysenteriae) bacteria. Out of six bacterial species (except Shigella dysenteriae and Vibrio cholera), four were found to be very sensitive to plant extract at all concentrations. The mean zone of inhibition for the extract against Gram positive and Gram negative bacteria increased with the increasing concentration of the extract. The highest mean zone of inhibition $(32 \mathrm{~mm})$ was recorded against Escherichia coli [59]. The water extract of aerial parts of Equisetum arvense possesses inhibitory effect on HIV-1 induced cytopathy [86].

\section{Effect on smooth muscles:}

The vasorelaxant activities of dicaffeoyl-meso-tartaric acid from Equisetum arvense was studied in isolated rat aorta strips. It showed slow relaxation activity against norepinephrine (NE)-induced contraction of rat aorta with/without endothelium. This compound did not affect contraction induced by a high concentration of potassium $\left(60 \mathrm{mM} \mathrm{K}{ }^{+}\right)$, while it inhibited NE-induced vasocontraction in the presence of nicardipine. The results showed that the inhibition of NE-induced vasocontraction was due to a decrease in calcium influx from the extracellular space caused by NE. In addition, dicaffeoyl tartaric acids showed vasorelaxant activity, regardless of their stereochemistry [87].Dried powdered plant material was extracted with alcohol. The extract obtained after the removal of the alcohol was triturated with petroleum-ether $\left(40-60^{\circ}\right)$ and then charcoaled, filtered and dried under vacuum. A $10 \mathrm{mg} / \mathrm{ml}$ solution/suspension of the extract (in distilled water) was added to the bath in 100-800 $\mathrm{ug} / \mathrm{ml}$ concentrations to study its effect on isolated guinea-pig ileum. The extract of Equisetum arvense antagonized the effect of acetylcholine on the isolated guinea-pig ileum preparation [88].

\section{Central nervous effect:}

In studying of sedative and anticonvulsant effects of Equisetum arvense, hydroalcoholic extract of Equisetum arvense (200 and $400 \mathrm{mg} / \mathrm{kg}$ ), it appeared that the extract possessed significant activity on the openfield, enhanced the number of falls in the rota-rod reducing the time of permanence in the bar and increased the sleeping time (46\% and $74 \%$ respectively ) in the barbiturate-induced sleeping time. In the pentylenetetrazoleseizure, it increased the first convulsion latency, diminished the severity of convulsions, reduced the percentage of animals which developed convulsion (50\% and $25 \%$ respectively) and protected animals from death. However, in the elevated plus maze, the doses 50,100 and $150 \mathrm{mg} / \mathrm{kg}$ did not affect the evaluated parameters [57]. The ethanolic extract of Equisetum arvense (50 and $100 \mathrm{mg} / \mathrm{kg}$ ) significantly increased the time-spent and the percentage of the open arm entries in the elevated plus-maze model, the effect was comparable to diazepam. Ethanolic extract $(100 \mathrm{mg} / \mathrm{kg})$ prolonged the ketamine-induced total sleeping time and decreased the locomotor activity in mice [89]. The sedative, pre-anesthetic and anti-anxiety effects of Equisetum arvense were studied in rats. The extract of Equisetum arvense was given at doses of (100, 200, $400 \mathrm{mg} / \mathrm{kg}$, ip) and Diazepam with dose of $(0.5 \mathrm{mg} / \mathrm{kg}$, ip). The hydroalcoholic extract of Equisetum arvense caused a significant increase in ketamine induced sleep and showed anxiolytic, sedative and preanesthetic effects at a dose of $200 \mathrm{mg} / \mathrm{kg}$ ip [90].The chronic administration of the hydroalcoholic extract of stems of Equisetum arvense (HAE) reversed the cognitive impairment in aged rats. Chronic administration of HAE at dose of $50 \mathrm{mg} / \mathrm{kg}$, ip, improved both short- and longterm retention of inhibitory avoidance task and ameliorated the cognitive performance in reference and working memory version of the Morris Water Maze. No differences were found between all three groups of young controls, aged controls and EHA-treated animals with regard to the open field and elevated plus maze tests. In vitro assays revealed that HAE diminished the thiobarbituric acid reactive substances as well as nitrite formation, but did not alter catalase activity. The authors concluded that the cognitive enhancement effects of the HAE may be attributed, at least in part, to its antioxidant action [91]. 


\section{Dermatological effects:}

The effect of Equisetum arvense 5\% on wound healing in rabbits was investigated and compared to povidone iodine and sodium chloride. Skin wounds were created on their dorsal aspect. Postoperatively, the wound surfaces were macroscopically examined, the healing process and the rates of wound expansion, contraction and epithelization were investigated. Biopsy specimens were collected on the $4,7,10$ and $14^{\text {th }}$ postoperative days to dedtermine neutrophil, macrophage infiltration, fibroblast and fibrosyctes. 5\% Equisetum arvense enhanced wound contraction comparable to povidone iodine and sodium chloridein at the $10^{\text {th }}$ day of the treatment. Differences in wound contraction of Equisetum arvense 5\% treated rabbits between postoperative $4^{\text {th }}$ days and postoperative $14^{\text {th }}$ days were significant but between $7^{\text {th }}$ and $14^{\text {th }}$ day was nonsignificant. However, in postoperative 4, 7, 10 and 14 days, the differences between the neutrophil, macrophage infiltration, fibroblast and fibrocytes were nonsignificant [92].

The effectiveness of Equisetum arvense ointment was evaluated in dermal wound (15 $\mathrm{mm} \times 15 \mathrm{~mm})$ healing in rats. The first group did not receive treatment while the second group was treated with a 1:1 mixture of vaseline and lanolin ointment. Equisetum arvense 5\% and 10\% ointments were used in the third and fourth groups. Equisetum arvense 5\% and $10 \%$ groups and the vaseline-lanolin group had a statistically significant higher wound closure ratio than the control group $(\mathrm{P}<0.05)$. Equisetum arvense ointment groups had a $95.26 \%$ and 99.96\% wound closure ratio $(\mathrm{P}<0.05)$ and higher dermal and epidermal regeneration, angiogenesis, and granulation tissue thickness after 14 days as compared to the other groups $(\mathrm{P}<0.05)$ [93].

The effectiveness of topical application of Equisetum arvense ointment 3\% in wound healing, reduction of inflammation and pain relief after episiotomy was studied in nulliparous mothers. A double-blind clinical trial was performed on 108 postpartum nulliparous mothers (54 women in horsetail group and 54 women in placebo group). About $5 \pm 1$ and $10 \pm 1$ days after the childbirth, the primary outcomes of episiotomy (wound healing and pain intensity) were assessed based on redness, edema, ecchymosis, discharge and approximation of the edges scale and a visual analogue scale (VAS). The number of used painkillers and the adverse events during the 10-day treatment period were also recorded. The mean scores were significantly lower in the treated group than the control group. The adjusted pain score difference after $5 \pm 1$ and $10 \pm 1$ days was -2.3 (95\% CI: -3.2 to -1.3 ) and 3.8 (95\% CI: -4.7 to -3.0$)$, respectively. The mean numbers of acetaminophen pills used in the control and treated group during the 10-day period of the study were $6.8 \pm 4.4$ and $11.6 \pm 7.1$, respectively $(\mathrm{P}<0.001)$. Accordingly, $3 \%$ Equisetum arvense ointment promoted wound healing and relieved pain during the 10-day period after episiotomy [94]. The HPCH ( Hydroxypropyl-Chitosan nail lacquer: a medical device intended to relieve symptoms and signs of nail dystrophy contained hydroxypropyl-chitosan ( $\mathrm{HPCH})$, Equisetum arvense and methylsulphonyl-methane) was evaluated in brittle nail compared to another nail lacquer (P-09-005) with identical composition, except for the presence of insoluble chitosan instead of HPCH. Thirty-four healthy women with onychoschizia of the fingernails were included. Both products were applied by all subjects once daily on the affected fingernails of either hand at random, for 4 weeks. The severity of nail signs was assessed using a 0-3 scale. Nail surface profilometry was assessed by morphometrical analysis of nail grooves on nail casts. Visual score of onychoschizia improved at T4 in 74\% of volunteers with HPCH nail lacquer and in 52\% with P-09-005 (Wilcoxon test $\mathrm{P}<0.05$ between treatments). Severe onychoschizia, present in $35 \%$ of patients at baseline, improved in $80 \%$ of subjects with HPCH nail lacquer and in $42 \%$ with P-09-005. On the morphometrical analysis a significant reduction of rugosity of the longitudinal nail grooves was noticed 19\% for $\mathrm{HPCH}$ nail lacquer and $16 \%$ for P-09-005 (not significant between treatments). Both products were well tolerated [95].

\section{Effect on immune system:}

The influence of crude Equisetum arvense protein on immune responses was investigated by measuring interleukin-2 (IL-2) and interferon- $\Upsilon$ (IFN- $\Upsilon$ ) produced by Th1 cells. After 24 -hour culture with $0.2 \mathrm{mg} / \mathrm{ml}$ of crude Equisetum arvense protein in the presence of $5 \mu \mathrm{g} / \mathrm{ml} \mathrm{ConA}, 1,434.5 \mathrm{pg} / \mathrm{ml}$ of IL-2 was produced, showing 1.7 times greater production than that in the control. In cells cultured for 48 hours, $2,130.9 \mathrm{pg} / \mathrm{ml}$ was produced by cells treated with $0.2 \mathrm{mg} / \mathrm{ml}$ of crude Equisetum arvense protein in the presence of $10 \mu \mathrm{g} / \mathrm{ml} \mathrm{ConA}$, showing 1.9 times greater production than that in the control. Regarding the IFN- $\Upsilon$ production-enhancing effect, $929.3 \mathrm{pg} / \mathrm{ml}$ was produced by cells cultured for 24 hours with $0.2 \mathrm{mg} / \mathrm{ml}$ of crude Equisetum arvense protein in the presence of $5 \mu \mathrm{g} / \mathrm{ml}$ ConA, suggesting that Th1 cells were activated [96].

\section{Antidiabetic effect:}

The methanolic extract of Equisetum arvense (50,100, 250 and $500 \mathrm{mg} / \mathrm{kg}$ daily for 5 weeks) was investigated for antidiabetic activity in streptozotocin-induced diabetic rats. The results showed that different doses of methanolic extract significantly lowered blood glucose. Also the weights of methanolic-extract treatment group were significantly higher. Concurrent histological studies of the pancreas of these animals showed comparable regeneration by methanolic extract which were earlier, necrosed by streptozotocin [97-99]. 


\section{Antinociceptive and anti-inflammatory effects:}

The antinociceptive and anti-inflammatory effects of hydroalcoholic extract of stem from Equisetum arvense were studied in mice. The extract $10,25,50$ and $100 \mathrm{mg} / \mathrm{kg}$, ip, reduced the writhing induced by acetic acid in $49,57,93$ and $98 \%$, respectively. In the formalin test, 50 and $100 \mathrm{mg} / \mathrm{kg}$, ip, reduced in 80 and $95 \%$ the licking activity in the first phase, but in the second phase only the latter dose diminished the licking time (35\%). In both phases, naloxone failed to revert the analgesic effect of the extract. In the hot-plate test, the extract at 100 and $200 \mathrm{mg} / \mathrm{kg}$ does not change the latency to licking or jumping. In the carrageenan-induced paw oedema, the extract at $50 \mathrm{mg} / \mathrm{kg}$, reduced the paw oedema $2 \mathrm{~h}(25 \%)$ and $4 \mathrm{~h}(30 \%)$ after carrageenan administration. The dose of $100 \mathrm{mg} / \mathrm{kg}$ caused reduction of the paw oedema (29\%) only $4 \mathrm{~h}$ after carrageenan administration [100].

\section{Effect on urinary system:}

The diuretic effect of EADE was assessed clinically by monitoring the volunteers' water balance over a $24 \mathrm{~h}$ period. The dried extract of Equisetum arvense $(900 \mathrm{mg} /$ day) produced a diuretic effect that was stronger than that of the negative control and was equivalent to that of hydrochlorothiazide without causing significant changes in the elimination of electrolytes. Only rare minor adverse events were reported [101].

The mechanism of action by which ethanol root extract of Equisetum arvense (EA) influences urinary bladder activity in rats was studied. The plant was extracted by hot ethanol (95\%). Rats in EA group were treated with a standard diet containing $0.2 \%$ of the extract, while rats in the control group were fed with the diet only. After 3 weeks, cystometry with $0.2 \%$ acetic acid solution and bladder activity was recorded, blood pressure, body weight and adenosine triphosphate were measured and $0.2 \%$ acetic acid solution was infused into the bladder and urinary adenosine triphosphate was determined before and after the stimulation. The results showed that during cystometry with acetic acid, the time interval between urinary bladder contractions was shorter and maximum bladder contraction pressure was much greater in rats in the control group, but in the Equisetum arvense group, the changes were much lower. Furthermore, in the Equisetum arvense group, plasma adrenaline and noradrenaline levels were lower than for the control group. In addition, increase in the levels of urinary adenosine triphosphate was smaller in Equisetum arvense group than in control group. The authors concluded that Equisetum arvense ethanol root extract influences urinary bladder activity by decreasing adenosine triphosphate release [102].

\section{Inhibition of platelet aggregation:}

The extract of Equisetum arvense produced a dose-dependent inhibition of thrombin and ADP-induced platelet aggregation. The effect of the plant could be related in part to the polyphenolic compounds present in the extract suggesting their involvement in the treatment or prevention of platelet aggregation complications linked to cardiovascular diseases [103].

\section{Hepatoprotective effect:}

Hepatoprotective activity-guided fractionation of the methanol extract of Equisetum arvense showed that onitin and luteolin isolated from the methanolic extract of Equisetum arvense possessed hepatoprotective activities on tacrine-induced cytotoxicity in human liver-derived Hep G2 cells, displaying $\mathrm{EC}_{50}$ values of $85.8 \pm 9.3$ microM and $20.2 \pm 1.4$ microM, respectively, while, Silybin, used as a positive control, showed $\mathrm{EC}_{50}$ value of $69.0 \pm 3.3$ microM [69].

\section{Anti-leishmanial effects:}

Equisetum arvense water extract showed anti-leishmanial effects. The number of Leishmania tropica decreased gradually by using 0.5 to $2.5 \mu \mathrm{g} / \mathrm{ml}$ concentrations of Equisetum arvense extract, Moreover, the extracts affected the number and time of generation, an inverse relationship was established between concentration of the extract and growth mean of the parasite. Inhibitory concentration of $50 \%$ of promastigotes $\left(\mathrm{IC}_{50}\right)$ was $1.5 \mu \mathrm{g} / \mathrm{ml}$, at logarithmic phase (96 hrs of cultivation). The Equisetum arvense dissolve in cold and hot water found to cause reduction in protein, carbohydrates and total nucleic acid contents in Leishmania tropica promastigotes that were treated with $\mathrm{IC}_{50}$ of the tested extracts [104].

\section{Effect on bones:}

The effects of hydromethanolic extract of Equisetum arvense was evaluated in human osteoclastogenesis in vitro. The extract reduced human osteoclast development and function, both in osteoclast precursor cell cultures and in cocultures of osteoclastic and osteoblastic cells. In studying of the effect of hydromethanolic extract on behavior of human bone marrow cells for osteoblastic modulation in vitro, the extract promoted osteoblastic response while preventing risk of infection at the biomaterial/ bone interface by local delivery system [105-106]. 


\section{Effect on RBC membrane stability:}

The effect of hydroalcoholic stem extract of Equisetum arvense on male rat RBC membrane stability was studied. Rats blood samples were exposed to 6,8 and $10 \mathrm{mg} / \mathrm{kg} / \mathrm{body}$ weight of hydroalcoholic horsetail extract. Membrane stabilizing activity was significantly decreased after exposure to extract compared to control group ( $\mathrm{P}<$ 0.0001) [107].

\section{Hyaluronidase inhibitory activity:}

The hyaluronidase inhibitory activity of Equisetum arvense extracts was investigated. The inhibitory effect of hyaluronidase was assayed using a Morgan microplate assay. The antioxidant activity of the Equisetum arvense extracts was measured on the basis of the scavenging activity of the stable 1,1- diphenyl 2-picrylhyorazyl (DPPH) free radical. Hyaluronidase inhibition of foliage and central stalk was $24.3 \%$ at $4.0 \mathrm{mg} / \mathrm{ml}$ and that of rhizomatous stem and root was $27.3 \%$ at same concentration [79].

\section{Side effects, contraindications and toxicity:}

In acute toxicity the plant extracts showed no side effects and mortalities up to $5000 \mathrm{mg} / \mathrm{kg} \mathrm{bw}$ in rats. In subacute toxicity study, no body weights changes, cumulative body weight gains, biochemical and hematological side effects were recorded in rats consume 0.3,1 and 3\% Equisetum arvense powder in diet. In a reverse mutation test, the number of revertant colonies on the plates treated with Equisetum arvense was not increased for S. typhimurium TA100, TA98, TA1535 or TA1537 or E. coli WP2uvrA. The test substance was not found to have mutagenic potential. In a chromosomal aberration test with Chinese hamster lung cells, the incidence of cells with chromosomal aberrations was lower than $5 \%$ both by the short treatment method and the continuous treatment method; the test substance was not found to have chromosomal aberration potential. In the micronucleus test in rats, the incidence of micronucleus was not significantly increased: the test substance was not found to have mutagenicity potential in vivo [108].However, the plant was possibly unsafe when taken by mouth long-term. It contained thiaminase, which breaks down the vitamin thiamine. This effect could lead to thiamine deficiency. Some products were labeled (thiaminase-free), but there was no enough information available for their safety. There was no enough information about the safety of taking horsetail in pregnant or breast-feeding weman. It was contraindicated in alcoholic people who, they were generally also thiamine deficient, therefore, taking horsetail might make thiamine deficiency worse. Horsetail lowered blood sugar levels in people with diabetes. Horsetail might flush potassium out of the body, possibly leading to decrease potassium levels. It used with caution in patient at risk for potassium deficiency [109]. Horsetail was also contraindicated in patients who have edema due to impaired heart and kidney function. A doctor should be consulted when the drug is utilized as a bath additive in cases of major skin lesions, acute skin lesions of unknown origin, major feverish and infectious diseases, cardiac insufficiency and hypertonia [55].Toxicity was recorded in animals, symptoms of Equisetum arvense poisoning were seen primarily in young, rapidly growing horses, cows and sheep. The symptoms of Equisetum arvense poisoning developed slowly. These included scruffy physical appearance, diarrhea and slight incoordination. Untreated poisoning will developed to loss of muscular control, staggering gait and nervousness. Animals may lie down and not be able to get up, may complain seizure and die within 1-2 weeks. Treatment should be oriented to remove the source of poisoning, Equisetum should not present in hay. Thiamine (vitamin B1) may be administered initially intravenously, then intramuscularly for several days [110]. The acute hepatotoxicity of Equisetum arvense (30,50, and $100 \mathrm{mg} / \mathrm{kg}$ for 14 days) was evaluated in rats. Blood samples were obtained to determine TGO, TGP, FA, DHL and GT-gamma activities. Hepatic tissue samples were collected for the anatomopathologic analysis. The anatomopathologic exam of the hepatic tissue showed lobular structure, however, there was no significant change in the activities of the hepatic enzymes when compared to control group [111].

\section{CONCLUSION}

The paper reviewed Equisetum arvense as promising medicinal plant with wide range of pharmacological activities which could be utilized in several medical applications because of its effectiveness and safety.

\section{REFERENCES:}

[1] Al-Snafi AE. Medicinal plants with anticancer effects (part 2)- plant based review. Sch Acad J Pharm 2016; 5(5): 175-193.

[2] Al-Snafi AE. Antiparasitic, antiprotozoal, molluscicidal and insecticidal activity of medicinal plants (part 2) plant based review. Sch Acad J Pharm 2016; 5(6): 194-207.

[3] Al-Snafi AE. Medicinal plants with antidiabetic effects (part 2): plant based review. IOSR Journal of Pharmacy 2016; 6(7): 49-61.

[4] Al-Snafi AE. Medicinal plants with antioxidant and free radical scavenging effects (part 2): plant based review. IOSR Journal of Pharmacy 2016; 6(7): 62-82. 
[5] Al-Snafi AE. Medicinal plants with antimicrobial activities (part 2): Plant based review. Sch Acad J Pharm 2016; 5(6): 208-239.

[6] Al-Snafi AE. Medicinal plants with cardiovascular effects (part 2): plant based review. IOSR Journal of Pharmacy 2016; 6(7): 43-62.

[7] Al-Snafi AE. Detoxification capacity and protective effects of medicinal plants (part 2): plant based review. IOSR Journal of Pharmacy 2016; 6(7): 63-84.

[8] Al-Snafi AE. Beneficial medicinal plants in digestive system disorders (part 2): plant based review. IOSR Journal of Pharmacy 2016; 6(7): 85-92.

[9] Al-Snafi AE. Immunological effects of medicinal plants: A review (part 2). Immun Endoc \& Metab Agents in Med Chem 2016; 16(2): 100-121.

[10] Al-Snafi AE. Medicinal plants affected male and female fertility (part 1)- A review. IOSR Journal of Pharmacy 2016; 6(10): 11-26.

[11] Al-Snafi AE. Antiparasitic effects of medicinal plants (part 1)- A review. IOSR Journal of Pharmacy 2016; 6(10): 51-66.

[12] Al-Snafi AE. Antimicrobial effects of medicinal plants (part 3): plant based review IOSR Journal of Pharmacy 2016; 6(10): 67-92.

[13] Al-Snafi AE. A review of medicinal plants with broncho-dilatory effect-Part 1. Scholars Academic Journal of Pharmacy, 2015; 5(7): 297-304.

[14] Al-Snafi AE. Medicinal plants with central nervous effects (part 2): plant based review. IOSR Journal of Pharmacy 2016; 6(8): 52-75.

[15] Al-Snafi AE. Adonis aestivalis: pharmacological and toxicological activities- A revew. Asian Journal of Pharmaceutical Science \& Technology 2016; 6(2): 96-102.

[16] Al-Snafi AE. The chemical constituents and therapeutic importance of Cressa cretica-A review. IOSR Journal of Pharmacy 2016; 6(6): 39-46.

[17] Al-Snafi AE. Medical importance of Cichorium intybus - A review IOSR Journal of Pharmacy 2016; 6(3): 41-56.

[18] Al-Snafi AE. The contents and pharmacological importance of Corchorus capsularis- A review. IOSR Journal of Pharmacy 2016; 6(6): 58-63.

[19] Al-Snafi AE. The chemical constituents and pharmacological effects of Convolvulus arvensis and Convolvulus scammonia- A review. IOSR Journal of Pharmacy 2016; 6(6): 64-75.

[20] Al-Snafi AE. Chemical constituents and pharmacological effects of Cynodon dactylon- A review. IOSR Journal of Pharmacy 2016; 6(7): 17-31.

[21] Al-Snafi AE. A review on Cyperus rotundus A potential medicinal plant. IOSR Journal Of Pharmacy 2016; 6(7): 32-48.

[22] Al-Snafi AE. A review on chemical constituents and pharmacological activities of Coriandrum sativum. IOSR Journal of Pharmacy 2016; 6(7): 17-42.

[23] Al-Snafi AE. Pharmacology and toxicology of Conium maculatum- A review. The Pharmaceutical and Chemical Journal 2016; 3(2):136-142.

[24] Al-Snafi AE. Therapeutic properties of medicinal plants: a review of plants with hypolipidemic, hemostatic, fibrinolytic and anticoagulant effects (part 1). Asian Journal of Pharmaceutical Science \& Technology 2015; 5(4): 271-284.

[25] Al-Snafi AE. Therapeutic properties of medicinal plants: a review of their antiparasitic, antiprotozoal, molluscicidal and insecticidal activity (part 1). J of Pharmaceutical Biology 2015; 5(3): 203-217.

[26] Al-Snafi AE. Therapeutic properties of medicinal plants: a review of plants with antidiabetic effects (part 1). J of Pharmaceutical Biology 2015; 5(3): 218-229.

[27] Al-Snafi AE. Therapeutic properties of medicinal plants: a review of plants with antifungal activity (part 1). Int J of Pharm Rev \& Res 2015; 5(3):321-327.

[28] Al-Snafi AE. Therapeutic properties of medicinal plants: a review of their dermatological effects (part 1). Int J of Pharm Rev \& Res 2015; 5(4):328-337.

[29] Al-Snafi AE. Therapeutic properties of medicinal plants: a review of plants with anticancer activity (part 1). Int $\mathrm{J}$ of Pharmacy 2015; 5(3): 104-124.

[30] Al-Snafi AE. Therapeutic properties of medicinal plants: a review of plants with anti-inflammatory, antipyretic and analgesic activity (part 1). Int J of Pharmacy 2015; 5(3): 125-147.

[31] Al-Snafi AE. Therapeutic properties of medicinal plants: a review of their immunological effects (part 1). Asian Journal of Pharmaceutical Research 2015; 5(3): 208-216.

[32] Al-Snafi AE. Therapeutic properties of medicinal plants: a review of their antibacterial activity (part 1). International Journal of Pharmacology and Toxicology 2015; 6(3): 137-158.

[33] Al-Snafi AE. Therapeutic properties of medicinal plants: a review of plants with antioxidant activity (part 1). International Journal of Pharmacology and Toxicology 2015; 6(3): 159-182. 
[34] Al-Snafi AE. Therapeutic properties of medicinal plants: a review of their respiratory effects ( part 1). International Journal of Pharmacological Screening Methods 2015; 5(2):64-71.

[35] Al-Snafi AE. Therapeutic properties of medicinal plants: a review of their antiviral activity (part 1). International Journal of Pharmacological Screening Methods 2015; 5(2): 72-79.

[36] Al-Snafi AE. Therapeutic properties of medicinal plants: a review of plants with cardiovascular effects (part 1). Int J of Pharmacology \& Toxicology 2015; 5(3): 163-176.

[37] Al-Snafi AE. Therapeutic properties of medicinal plants: a review of medicinal plants with central nervous effects (part 1). Int J of Pharmacology \& Toxicology 2015; 5(3): 177-192.

[38] Al-Snafi AE. Medicinal plants possessed anti-inflammatory antipyretic and analgesic activities (part 2)- plant based review. Sch Acad J Pharm 2016; 5(5): 142-158.

[39] Al-Snafi AE. Medicinal plants affected reproductive systems (part 2) - plant based review. Sch Acad J Pharm 2016; 5(5): 159-174.

[40] Al-Snafi AE. The pharmacological and toxicological effects of Coronilla varia and Coronilla scorpioides: A review. The Pharmaceutical and Chemical Journal 2016; 3(2): 105-114.

[41] Al-Snafi AE. Pharmacological activities of Cotoneaster racemiflorus- A review. The Pharmaceutical and Chemical Journal 2016, 3(2):98-104.

[42] Al-Snafi AE. The pharmacological and toxicological effects of Coronilla varia and Coronilla scorpioides: A Review. The Pharmaceutical and Chemical Journal 2016, 3(2):105-114.

[43] Al-Snafi AE. The constituents and pharmacology of Corchorus aestuans: A review. The Pharmaceutical and Chemical Journal 2016; 3(4):208-214.

[44] Al-Snafi AE. The chemical constituents and pharmacological activities of Cymbopagon schoenanthus: A review. Chemistry Research Journal 2016; 1(5):53-61.

[45] Al-Snafi AE. Traditional uses, constituents and pharmacological effects of Cuscuta planiflora. The Pharmaceutical and Chemical Journal 2016; 3(4): 215-219.

[46] Al-Snafi AE. The constituents and pharmacology of Cnicus benedictus- A review. The Pharmaceutical and Chemical Journal 2016; 3(2):129-135.

[47] Al-Snafi AE. Medicinal importance of Colchicum candidum-A review. The Pharmaceutical and Chemical Journal 2016; 3(2):111-117.

[48] Al-Snafi AE. Nutritional value and pharmacological importance of citrus species grown in Iraq. IOSR Journal of Pharmacy 2016; 6(8): 76-108.

[49] Al-Snafi AE. Pharmacological activities of Cotoneaster racemiflorus- A review. The Pharmaceutical and Chemical Journal 2016; 3(2): 98-104.

[50] Al-Snafi AE. Therapeutic properties of medicinal plants: a review of their detoxification capacity and protective effects (part 1). Asian Journal of Pharmaceutical Science \& Technology 2015; 5(4): 257-270.

[51] Common horsetail, field horsetail, http://science. halleyhosting. com/nature/ basin/ horsetail/arvense.html

[52] United States Department of Agriculture, Natural resources conservation service, http://plants.usda.gov/core/profile?symbol=eqar

[53] U.S. National Plant Germplasm System, Equisetum arvense, https://npgsweb. arsgrin.gov/gringlobal/taxonomydetail.aspx?400386

[54] Flora of North America, Equisetum arvense, http://www.efloras.org/ florataxon. aspx?flora_id=1\&taxon_id=233500616

[55] Asgarpanah J and Roohi E. Phytochemistry and pharmacological properties of Equisetum arvense L. Journal of Medicinal Plants Research 20112; 6(21): 3689-3693.

[56] Sandhu NS, Kaur S and Chopra D. Pharmacognostic evaluation of Equisetum arvense Linn. Int J PharmTech Res 2010; 2(2): 1460-1464.

[57] Dos Santos Jr JG, Blancoa MM, Do Monteb FHM, Russib M, Lanziottib VNMB, Lealc LKAM and Cunhac GM. Sedative and anticonvulsant effects of hydroalcoholic extract of Equisetum arvense. Fitoterapia 2005; 76(6): 508-513.

[58] Mimica-Dukic N, Simin N, Cvefic J, Jovin E, Orcic D and Bozin B. Phenolic compounds in field horsetail (Equisetum arvense L) as natural antioxidants. Molecule 2008; 13: 1455-1464.

[59] Sinha NS. In vitro antibacterial activity of ethanolic extract of Equisetum arvense L. International Journal of Pharmaceutical and Biological Research 2012; 3(1): 19121.

[60] Briskin DP. Medicinal plants and phytomedicines. Linking plant biochemistry and physiology to human health. Plant Physiol 2000; 124(2):507-514.

[61] Milovanović V, Radulović N, Todorović Z, Stanković M and Stojanović G. Antioxidant, antimicrobial and genotoxicity screening of hydro-alcoholic extracts of five Serbian Equisetum species. Plant Foods Hum Nutr 2007; 62(3):113-119. 
[62] Stajner D, Popović BM, Canadanović-Brunet J and Anackov G. Exploring Equisetum arvense L., Equisetum ramosissimum L. and Equisetum telmateia L. as sources of natural antioxidants. Phytother Res 2009; 23(4):546-550.

[63] Sandhu NS, Kaur S and Chopra D. Equisetum aervens: Pharmacology and Phytochemistry - A review. Asian J Pharmaceut Clin Res 2010; 3: 146-150.

[64] Carnet A, Petitjean-Freytet C, Muller D and Lamaison JL. Content of major constituents of horsetails, Equisetum arvense L. Plants Med Phytother 1991; 25: 32-38.

[65] Holzhueter G, Narayanan K and Gerber T. Structure of silica in Equisetum arvense. Anal Bioanal Chem 2003; 376: 512-517.

[66] Sola-Rabada A, Rinck J, Belton DJ, Powell AK and Perry CC. Isolation of a wide range of minerals from a thermally treated plant: Equisetum arvense, a Mare's tale. JBIC Journal of Biological Inorganic Chemistry 2016; 21(1): 101-112.

[67] Cetojevic-Simin DD, Canadanovic-Brunet JM, Bogdanovic GM, Djilas SM, Cetkovic GS, Tumbas VT and Stojiljkovic BT. Antioxidative and antiproliferative activities of different horsetail (Equisetum arvense L.) extracts. J Med Food 2010; 13(2): 452-459.

[68] Canadanovic-Brunet JM, Cetkovic GS, Djilas SM, Tumbas VT, Savatovic SS, Mandic AI, Markov SL and Cvetkovic DD. Radical scavenging and antimicrobial activity of horsetail (Equisetum arvense L.) extracts. Int J Food Sci Tech 2009; 44(2):269-278.

[69] Oh H, Kim DH, Cho JH and Kim YC. Hepatoprotective and free radical scavenging activities of phenolic petrosins and flavonoids isolated from Equisetum arvense. J Ethnopharmacol 2004;95(2-3):421-424.

[70] European Medicines Agency; Community herbal monograph on Equisetum arvense L.. HERBA., Doc. Ref. EMEA/HMPC/394895/2007, (2008).

[71] Neda MD, Natasa S, Jelena C, Emilija J, Dejan O and Biljana H. Phenolic compounds in field horsetail (Equisetum arvense L.) as natural antioxidants. Molecules 2008; 13: 1455-1464.

[72] PDR for Herbal Medicines. Medical Economics Company, Inc. at Montvale, 2000: 409.

[73] Carneiro DM, Tresvenzol LMF, Jardim PCBV and Cunha LC. Equisetum arvense: Scientific evidences for clinical use. IJBPAS 2013; 2(8): 1579-1596.

[74] Jun C, Li-Jiang X and Ya-Ming X. Three new phenolic glycosides from the fertile sprouts of Equisetum arvense. Acta Botanica Sinica 2001;43(2):193-197.

[75] Niko Radulović, Gordana Stojanović and Radosav Palić. Composition and antimicrobial activity of Equisetum arvense L. essential oil. Phytotherapy Research 2006; 20(1): 85-88.

[76] Alexandru V, Gaspar A, Savin S, Toma A, Tatia R and Gille E. Phenolic content, antioxidant activity and effect on collagen synthesis of a traditional wound healing polyherbal formula. Studia Universitatis "Vasile Goldiş", Seria Ştiinţele Vieţii 2015; 25(1):41-46.

[77] Uslu ME, Erdogan I, Oguzbayraktar O and Ates M. Optimization of extraction conditions for active components in Equisetum arvense extract. Romanian Biotechnological Letters 2013; 18(2): 8115-8131.

[78] Nagai T, Myoda T and Nagashima T. Antioxidative activities of water extract and ethanol extract from field horsetail (Tsukushi) Equisetum arvense L. Food Chem 2005; 91(3):389-394.

[79] Huh MK and Han MD. Inhibitory effect of hyaluronidase and DPPH radical scavenging activity using extraction of Equisetum arvense. Journal of Advanced Research in Biological and Life Sciences 2015; 3(2): 47-51.

[80] Alexandru V, Petrusca DN and Gille E: Investigation of pro-apoptotic activity of Equisetum arvense L. water extract on human leukemia U 937 cells. Romanian Biotechnological Letters 2007;12(2):3139-3147.

[81] Trouillasa P, Callistea CA, Allaisc DP, Simonb A, Marfaka A, Delageb C and Durouxa JL. Antioxidant, anti-inflammatory and antiproliferative properties of sixteen water plant extracts used in the Limousin countryside as herbal teas. Food Chemistry 2003; 80: 399-407.

[82] Aldaas SA. Cytotoxic and antibacterial activity of an extract from a Saudi traditional medicinal plant Equisetum arvense. MSc thesis, King Abdullah University of Science and Technology, Thuwal 2011.

[83] Yoshinobu Y. Antitumor activity of crude protein extracted from Equisetum arvense LINN'E. Journal of Analytical Bio-Science 1992; 22:421-424.

[84] Yoshinobu Y, Takashi I and Jiharu H. Crude protein extracted from Equisetum arvense LINN'E increases the viability of cancer cell in vivo. Journal of Analytical Bio-Science 2004; 27: 409-412.

[85] Geetha RV, Lakshmi T and Roy A. In vitro evaluation of antibacterial activity of Equisetum arvense Linn on urinary tract pathogens. International Journal of Pharmacy and Pharmaceutical Sciences 2011; 3(4): 323-325.

[86] Yu YB, Park JC, Lee JH, Kim GE, Jo SK, Byun MW and Hattori M. Screening of some plants for inhibitory effects on HIV-1 and its essential enzymes. Korean J Pharmacog 1998; 29(4): 338-346.

[87] Sakurai N, Iizuka T, Nakayama S, Funayama H, Noguchi M and Nagai M. Vasorelaxant activity of caffeic acid derivatives from Cichorium intybus and Equisetum arvense. Yakugaku Zasshi 2003;123(7):593-598. 
[88] Qsyum A, Ahmed N, Ahmad KD and Khattak SG. Pharmacological screening of medicinal plants (II). J Pakistan Med Assoc 1983; 33: 136-138.

[89] Singh N, Kaur S, Bedi PMS and Kaur D. Anxiolytic effects of Equisetum arvense Linn extracts in mice. Indian journal of experimental biology 2011; 49(5):352-356.

[90] Rezaie A, Ahmadizadeh C, Mosavi G, Nazeri M, Jafari B and Ebadi R. Comparative study of sedative, preanesthetic and anti-anxiety effect of Equisetum arvense (horse's Tail) extract with diazepam on rats. Australian Journal of Basic and Applied Sciences 2011; 5(10): 786-789.

[91] Guilherme dos Santos J Jr, Hoffmann Martins do Monte F, Marcela Blanco M, Maria do Nascimento Bispo Lanziotti V, Damasseno Maia F and Kalyne de Almeida Leal L. Cognitive enhancement in aged rats after chronic administration of Equisetum arvense L. with demonstrated antioxidant properties in vitro. Pharmacol Biochem Behav 2005; 81(3): 593-600.

[92] Hayat A, Temamogullari F, Yilmaz R and Karabulut O. Effect of Equisetum arvense on wound contraction of full-thicnes skin wound in rabbits. Journal of Animal and Veterinary Advances 2011; 10(1): 81-83.

[93] Azay Y, Ozyurt S, Guzel S, Cimbiz A, Olgun EG and Cayci MK. Effect of Equisetum arvense ointment on dermal wound healing in rats. Wounds 2010; 22(10): 261-267.

[94] Asgharikhatooni A, Bani S, Hasanpoor S, Alizade SM, and Javadzadeh Y. The effect of Equisetum arvense (horse tail) ointment on wound healing and pain intensity after episiotomy: A randomized placebocontrolled trial. Iran Red Crescent Med J 2015; 17(3): e25637. doi: 10.5812/ircmj.25637

[95] Sparavigna A, Caserini M, Tenconi1 B, Ponti1 ID and Palmieri R. Effects of a novel nail lacquer based on hydroxypropyl-chitosan $(\mathrm{HPCH})$ in subjects with fingernail onychoschizia. J Dermatolog Clin Res 2014; 2(2): 1013.

[96] Yukitake J and Yamamoto Y. Enhancement of cytokine (IL-2, INF- $\Upsilon$ ) production in Th1 cells by crude protein extract of Equisetum arvense Linne. Journal of Analytical Bio-Science 2011; 34(5): 339-344.

[97] Safiyeh S, Fathallah F, Vahid N, Habib SS and Nabat N. Effect of Equisetum arvense L. (Equisetaceae) in microalbuminuria and creatinine excretion in streptozotocin-induced diabetes in male rats. Int $\mathbf{J}$ Pharmacology 2007; 3(2): 155-159.

[98] Safiyeh S, Fathallah FB, Vahid N, Hossine N and Habib SS. Antidiabetic effect of Equisetum arvense L. (Equisetaceae) in streptozotocin-induced diabetes in male rats. Pak J Biol Sci 2007; 10(10): 1661-1666.

[99] Soleimani S, Azarbaizani FF and Nejati V. The Effect of Equisetum arvense L. (Equisetaceae) in histological changes of pancreatic $\beta$-cells in streptozotocin-induced diabetic in rats. Pakistan Journal of Biological Sciences 2007; 10(23): 4236-4240.

[100] Do Monte FH, dos Santos JG Jr, Russi M, Lanziotti VM, Leal LK and Cunha GM. Antinociceptive and anti-inflammatory properties of the hydroalcoholic extract of stems from Equisetum arvense L. in mice. Pharmacol Res 2004; 49(3):239-243.

[101] Carneiro DM, Freire RC, Honório TC, Zoghaib I, Cardoso FFS, Tresvenzol LMF, Paula JR, Sousa ALL, Jardim PCBV and Cunha LC. Randomized, double-blind clinical trial to assess the acute diuretic effect of Equisetum arvense (field horsetail) in healthy volunteers. Evidence-Based Complementary and Alternative Medicine 2014, http://dx.doi.org/10.1155/2014/760683

[102] Zhang H, Li N, Li K and Li P. Effect of ethanol root extract of Equisetum arvense (L) on urinary bladder activity in rats and analysis of principal plant constituents. Tropical Journal of Pharmaceutical Research August 2015; 14 (8): 1451-1458.

[103] Mekhfi H, El Haouari M, Legssyer A, Bnouham M, Aziz M, Atmani F, Remmal A and Ziyyat A. Platelet anti-aggregant property of some Moroccan medicinal plants. J Ethnopharmacol 2004; 94(2-3): 317-322.

[104] Saeed BQ, Hassan HF and Arteen HI. Effect of some medical plant extracts on metabolism of Leishmania tropica promastigotes in vitro. J Med Microb Diagn 2014; 3(4): 165. doi:10.4172/2161-0703.1000165

[105] Pereira BC, Gomes SP, Almeida Palmas R, Vieira L, Ferraz M, Lopes M and Fernandes M. Equisetum arvense hydromethanolic extracts in bone regeneration: in vitro osteoblastic modulation and antibacterial activity. Cell Proliferation 2012; 45: 386-396.

[106] Costa-Rodrigues J, Carmo CS, Silva J and Fernandes M. Inhibition of human in vitro osteoclastogenesis by Equisetum arvense. Cell Proliferation 2012; 45: 566-576.

[107] Shadanyian M, Ahmadi R, Syiavashi M and Alaee Z. The effects of hydroalcoholic stem extract of Equisetum arvense on male rat RBC membrane stability. International Conference on Food, Biological and Medical Sciences 2014; (FBMS-2014): 54-56.

[108] European commission, A pilot project: proposal for approbation of basic substances, in the context of regulation (EC) N 1107/2009 Equisetum arvense. http://www. itab. asso.fr/downloads/comintrants/4096_dar-4p_rapport-technique_final_annexes.pdf

[109] WebMed, Horsetail, http://www.webmd.com/vitamins-supplements /ingredient mono-843 horsetail.aspx ?activeingredientid $=843 \&$ active ingredient name=horsetail 
[110] Bebbington A. Toxicity of Equisetum to horses, http://www.omafra.gov. on.ca/ english/livestock/horses/facts/07-037.htm

[111] Baracho NCV, Vicente BBV, Arruda GAS, Sanches BCF and Brito J. Study of acute hepatotoxicity of Equisetum arvense L. in rats. Acta Cir Bras 2009; 24(6) 449-453. 